\title{
ŽALIO PIENO VIDAUS RINKOS STRUKTŪRA IR KONCENTRACIJA LIETUVOJE
}

\author{
Vlada Vitunskienè \\ Prof. dr. Vytauto Didžiojo universitetas \\ Adresas: K. Donelaičio g. 58, 44248, Kaunas, Lietuva \\ El. paštas vlada.vitunskiene@vdu.lt
}

Gauta 201911 11, Priimta 20191208

\begin{abstract}
Straipsnyje sprendžiama žalio pieno rinkos ir pasiūlos, ir paklausos koncentracijos lygio vertinimo problema, kai tyrèjams pasiekiama labai ribota informacija apie pardavimus ir pirkimus individualiu pieno gamintojų (t. y. pardavejjų) bei pieną perdirbančių imonių ar kitų pieną perparduodančių tarpininkų (t. y. pirkèjų) lygmeniu. Pasitelkus abstraktaus modeliavimo, normalizuotos Lorenco kreivès, koncentracijos laipsnio (RC) ir Herfindalio-Hiršmano indekso (HHI) bei jų dinamikos palyginamosios analizès būdus, išplètotas žalio pieno rinkos struktūros hipotetinis modelis ir nustatytas Lietuvos žalio pieno vidaus rinkos koncentracijos lygis. Empirinio tyrimo rezultatai parode, kad, viena vertus, žalio pieno pasiūla vidaus rinkoje dekoncentruota, o neasocijuoti kooperatyvai gamintojų realios derybinès galios rinkoje nesukuria. Antra vertus, didelès RC6 reikšmès šią rinką leidžia klasifikuoti kaip oligopsoninę, turinčią beveik stabilų (po $2009 \mathrm{~m}$. ekonomikos krizės šiek tiek sumažèjusį) pirkèjų koncentracijos laipsnį.

Raktiniai žodžiai: pirkèjų koncentracija, žalio pieno rinka, oligopsonija, kooperatyvai, pieno perdirbëjai
\end{abstract}

JEL kodai: L40, O13, Q13.

\section{Ivadas}

Didejantis maisto grandinès konsolidavimas ir vertikalusis koordinavimas sudare galimybę galingiems maisto pramonininkams ir mažmenininkams piktnaudžiauti rinkos galia. Visame pasaulyje didejja politinis susirūpinimas dèl tokio piktnaudžiavimo galimo poveikio ūkininkų bei vartotojų gerovei ir žemės ūkio efektyvumui (Sexton, Xia, 2018). Politikos formuotojai ir analitikai atkreipé dėmesị i daugelyje šalių susidariusią galimybę dideliems maisto pramoninkams ir (arba) mažmenininkams mažinti ūkininkų tiekiamų produktų kainas dẻl išaugusios jų perkamosios galios rinkoje (Madau, Furesi, Pulina, 2016). Lietuvoje nuo $2002 \mathrm{~m}$. Vyriausybė kelis kartus inicijavo tyrimą dẻl didžiausių pieną perdirbančių įmonių piktnaudžiavimo mažinant žalio pieno supirkimo kainas vidaus rinkoje.

Vienas iš svarbių klausimų yra rinkos koncentracijos, kaip specifinio rinkos galios mato, aspektas. Pasak Pavic, Galetic, Piplica (2016), rinkos koncentracijos matavimo klausimas yra visada aktualus mokslo ir profesinei bendruomenei.

Copyright (C) 2019 The Authors. Published by Vytautas Magnus University. This is an open-access article distributed under the terms of the Creative Commons Attribution-NonCommercial 4.0 (CC BY-NC 4.0) license, which permits unrestricted use, distribution, and reproduction in any medium, provided the original author and source are credited. The material cannot be used for commercial purposes. 
Jis yra ypač svarbus pastaraisiais metais dèl globalizacijos procesų paskatintos susijungimo bangos ịvairiose pramonès šakose ir dèl to pasikeitusios koncentracijos daugelyje rinkų. Taigi ieškoma atsakymo ị klausimą, kaip ịvertinti ir paaiškinti rinkos koncentraciją, ypač atsižvelgiant ị konkurencijos iškraipymą, ir kaip apibrèžti rinkos galią. Dar praẻjusio amžiaus aštuntajame dešimtmetyje Lustgarten (1975) atkreipé dèmesi i tai, kad nors ekonomikos teorija ir numato monopsonijos paplitimą kaip svarbų rinkos struktūros elementą, tačiau empirinejje literatūroje išimtinai nagrinèjama pardavejų struktūra, nes, kaip pastebèjo Guth, Schwartz, Whitcomb (1976), pramonès organizacijos literatūroje iš esmès nekreipiama dèmesio ị pirkèjų struktūrą. Be to, anot autorių, pirkèjų rinkos koncentracijos lygio negalima nustatyti iš viešai prieinamų duomenų, nes juose pirkimai nèra klasifikuojami pagal produktus ir perkančiąsias įmones. Ši duomenų problema tyrejjams išliko aktuali iki šių dienų, ypač žemès ūkio produktų rinkoje.

Dèl tyrejams neprieinamų duomenų apie žalio pieno pirkimus pagal perkančiąsias įmones problemos, daugumoje mokslinès literatūros šaltinių pirkèjų galia - oligopsoninè elgsena - žalio pieno rinkoje nagrinejjama modeliavimui pasitelkiant kainų indeksų pieno tiekimo grandinejje laiko eilutes, maisto pramonès įmonių veiklos duomenis, pavyzdžiui: kainų perdavimo visoje tiekimo grandinèje modeliavimas (Madau, Furesi, Pulina, 2016); rinkos galios indekso modeliavimas (Grau, Hockmann, 2018); gamintojams mokamų pieno kainų ir pramonès koncentracijos Grangerio priežastingumo analizè (Cavalheiro, Vieira, Costa, 2015), gamybos funkcijos ir pelno maksimizavimo sąlygų parametrų modeliavimas (Stalgienè, Jedik, 2015; Stalgiene, Jedik, Viira, Krievina, 2017) ir kt.

Tyrimo objektas - žalio pieno rinkos koncentracija, empiriniam tyrimui naudojant duomenis apie žalio pieno supirkimą pagal perkančias įmones ir žalio pieno pardavimą pagal laikomų karvių bandos dydị.

Tyrimo tikslas - parengus žalio pieno rinkos struktūros hipotetinį modelị, nustatyti Lietuvos žalio pieno vidaus rinkos koncentracijos lygị.

Tyrimo metodai - abstraktus modeliavimas, normalizuotos Lorenco kreivès, koncentracijos laipsnio (RC) ir Herfindalio-Hiršmano indekso (HHI) bei jų dinamikos palyginamoji analizè.

\section{Empirinio tyrimo koncepcija, metodika ir apribojimai}

\section{1. Žalio pieno rinkos struktūros hipotetinis modelis}

Pagal standartinę žemès ūkio produktų rinkos struktūros koncepciją žalio pieno rinka ekonomikos teorijoje klasifikuojama kaip tobula konkurencija, kurią apibūdina 1 paveikslo dešinèje pusejje atvaizduoti rinkos struktūros elementų bruožai, t. y.: daug pieno gamintojų; žalias pienas vienoda, standartiné žaliava perdirbimui; santykinai menkos patekimo ị žalio pieno rinką arba pasitraukimo iš jos kliūtys; daug žalio pieno pirkèjų. Arba paprasčiau, kaip teigè Wessels (1997, cituota iš Cavalheiro, Vieira, Costa, 2015, p. 627), tai rinka, kuriai priklauso gerai standartizuota preké, kurią gamina daugelis ūkių, be jokių kliūčių galima patekti ị rinką, joje daugybè tokių pačių 
gamintojų ir informacijos lygybė. Gi reikia atsižvelgti, kad šie bruožai veikiau vaizduoja hipotetinę, o ne dabartinę realią situaciją žalio pieno rinkoje.

Žvelgiant iš pasiūlos pusès, pieną gamina labai daug ūkių, dèl to kiekvieno jų (net ir didžiausias karvių bandas laikančių) parduodamas žalio pieno kiekis, palyginus su bendrosios pasiūlos apimtimi, yra toks mažas, jog nė vienas individualiai neturi derybinès galios rinkoje. Be to, dauguma didesnių pieno gamintojų yra specializuoti ūkiai, daug investavę $\mathfrak{i}$, anot Sexton, Zhang (2001), negrižtamą turtą, kuris tampa kliūtimi šiems ūkiams pasitraukti iš rinkos, o tai, savo ruožtu, lemia neelastingą pieno produktų pasiūlą.

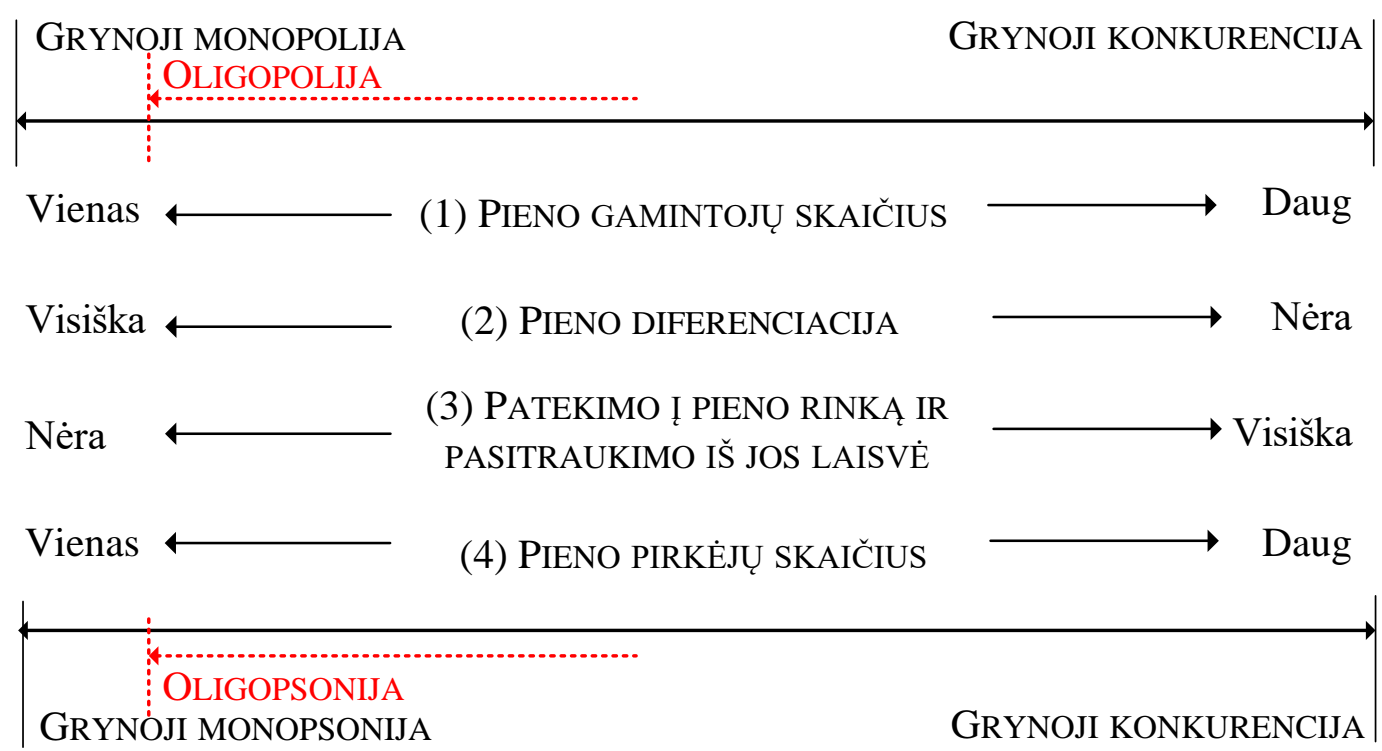

Pastaba: Cramer, Jensen, Southgate (1997) rinku klasifikacijos triju kriteriju (gamintoju skaičiaus, produktu diferenciacijos bei iejjimo ir išejimo ì rinka laisvès) modelio schema autorès papildyta ketvirtuoju - pirkëju skaičiaus - kriterijumi bei tokiais rinkos struktūros elementais, kaip oligopolija, monopsonija bei oligopsonija, ir pritaikyta žalio pieno rinkai.

1 pav. Žalio pieno rinkos struktūros klasifikacijos elementai

Žvelgiant iš paklausos pusès, neelastinga ūkiu pasiūla ir didelè perdirbimui skirto žalio pieno pirkèjų koncentracija rinkoje sudaro struktūrines sąlygas, kurios padeda didžiausioms pieno pramonès įmonèms vykdyti pirkẻjų galią, kaip atvaizduota 1 paveikslo kairèje pusèje. Oligopsoninè praktika yra labiau tikètina tada, kai mažas rinkoje pirmaujančių įmonių skaičius superka didžiają žalio pieno dalį, nei tada, kai net ir didžiausios pieno perdirbimo pramonès i̇monès yra santykinai perka mažai. Ekonomikos teorija nurodo, kad pirkèjų koncentracija yra svarbus elgsenos ir kainų veiksnys rinkoje. Dar praejjusio šimtmečio viduryje tyrinèdamas rinkos galią ir dèl jos ūkininkams kylančias problemas JAV, Lanzillotti (1960, cituota iš Rogers, 2001, p. 8) nustatè, kad ,ūkininkai, kaip pardavejjai, atsidūrè oligopsonijų, slaptų susitarimų ir monopsonijos malonejje“. Kaip pastebejjo Sexton, Zhang (2001), tokia galia tiesiogiai 
veikia ne vien žemès ūkio produktų gamintojus, bet ir maisto vartotojus. Perdirbejjai mažindami ūkių produktų kainas skatina ūkininkus mažinti gamybą ir pardavimą, taip per prekybos grandinę sukeldami maisto kainas ir sumažindami gerovę maisto vartotojams.

Dabartinèse maisto tiekimo gandinèse daugelis tradicinių žemės ūkio produktų rinkų (tarp jų ir žalio pieno) yra keičiamos vertikalia integracija, strateginèmis sajungomis ar sutartimis (Rogers, 2001). Jos taip pat veikiamos gamintoju ,jungtinès veiklos" organizacijų, tokių kaip pardavimo kooperatyvai, gamintojų organizacijos ir pan. (OECD, 2005). Kooperatyvai ar gamintojų organizacijos yra kaip atsakas ị silpną pavienių ūkių derybinę galią rinkoje. Kooperatyvų rinkos dalis ES žalio pieno rinkoje sudaro apie 55 proc. (Müller, Hanisch, Malvido, et al., 2018). JAV 50 ūkininkams priklausančių geriausių pieno kooperatyvų sudaro beveik 80 proc. šios šalies žalio pieno rinkos (Cavalheiro, Vieira, Costa, 2015). Lietuvoje kooperatyvai superka apie 29 proc. perdirbimui skirto žalio pieno vidaus rinkoje. Tiek teoriniai modeliai, tiek empiriniai duomenys rodo, kad didelès ūkininkams priklausančių ir kontroliuojamų kooperatyvų rinkos dalys gali priversti pieną perdirbančias įmones mokèti didesnes kainas pieno gamintojams. Taip pat kooperatyvai gali priversti jas sumažinti kainų svyravimą. Müller, Hanisch, Malvido, et al. (2018), išnagrinejję įvairių laikotarpių empirinių tyrimų rezultatus, teigia, kad oligopsoninèse rinkose kooperatyvai užtikrina aukštesnes pieno ir kitų žemès ūkio produktų kainas regionuose. Tai padeda pateisinti politiką, palankią atviros narystès kooperatyvams, gamintojų organizacijoms ir kitokioms gamintojų jungtinès veiklos organizacijoms, kurių kaip konkuruojančios jègos buvimas mažina pelno siekiančių pieno pramonès įmonių galimybes naudotis monopsonijos galia.

\subsection{Pirkèjų koncentracijos matavimo būdai}

Rinkos koncentracija rodo rinkos sutelktumą didžiausių įmonių rankose. Tai dažnai laikoma konkurencijos intensyvumo rodikliu (OECD, 2018). Padidèjęs koncentracijos rinkoje lygis reiškia konkurencijos sumažejimą (Cavalheiro, Vieira, Costa, 2015).

\section{Koncentracijos kreivès}

Rinkos koncentracija gali būti nustatoma skirtingais būdais arba naudojant skirtingus rodiklius. Kaip pastebejo Rosenbluth (1955), kiekvienam vaizduotę turinčiam tyrejui labai parastas ir naudingas būdas rinkos koncentracijai apibūdinti yra „koncentracijos kreive““. Ekonominèje analizejje koncentracijos kreivè naudojama kaip metodas sąsajoms tarp skirtingų ekonominių kintamujų pasiskirstymo nagrinèti. Ji iliustruoja, kaip vienas kintamasis pasiskirsto pagal kito kintamojo dydi populiacijoje (Van Kerm, Jenkins, 2001). Terminas „,koncentracijos kreive““ pasiskolintas iš pajamų pasiskirstymo ir nelygybès literatūros, kurioje šios kreivès koncepcija ir buvo išplètota (Yitzhaki, Olkin, 1991). Pajamų ir turto pasiskirstymui pagal dydị vaizduoti kaip patogi grafinè priemonè plačiai naudojama Lorenco kreivè. Pajamas pakeitus pirkejju skaičiumi, o kumuliatyviają pajamų paskirstymo funkciją (cdf) pakeitus jų rinkos dalių cdf, Lorenco kreivė gali būti naudojama rinkos pasiskirstymo tarp pirkèjų nelygybei 
grafiškai atvaizduoti (Hanson, Simmons, 1995). Koncentracijos analizèje santykinė Lorenco kreivè normalizuojama atsižvelgiant ij bendrą analizuojamo rezultato kintamaji tam tikroje populiacijoje ar subpopuliacijoje (Kakwani, 1977).

Pavyzdžiui, Wysokinski, Baran, Florkowski (2015) Lorenco kreivès metodą pritaikè žalio pieno pardavimų pasiskirstymui pagal šalis ES bendrojoje rinkoje analizuoti.

Du kintamieji yra svarbūs rinkos koncentracijos lygiui nustatyti - tai įmonių skaičius ir jų santykinis pasiskirstymas rinkoje pagal dydị (Cavalheiro, Vieira, Costa, 2015). Rinkoje dalyvaujančių įmonių dydis gali būti matuojamas pagal pardavimus, pirkimus, turtą, užimtumą, pridètinę vertę ar kitus kintamuosius, kurie gali būti naudojami koncentracijai apibūdinti. Tačiau manoma, kad visuotinio atsakymo ị šs klausimą nèra. Dèl to ịmonių dydžio matą reikètų pritaikyti atsižvelgiant ị analizuojamus koncentracijos klausimus ar problemas (Hall, Tideman, 1967). Šiame tyrime nagrinejjami Lietuvos vidaus rinkos duomenys apie supirktą žalią pieną perdirbimui pagal ji superkančių ịmonių (tarp jų ir kooperatyvų) dydį. Normalizuota Lorenco kreivè naudojama pirkèjų pasiskirstymo pagal superkamo pieno kieki Lietuvos žalio pieno vidaus rinkoje analizei, daugiausia dèmesio skiriant galimam pirkejjų koncentracijos lygiui ir rinkos struktūros tipui nustatyti.

\section{Koncentracijos rodikliai}

Žinoma keletas rinkos koncentracijos rodiklių. Vieni jų (koncentracijos laipsnis (RC) ir Herfindalio-Hiršmano indeksas (HHI)) yra labai paprasti ir lengvai apskaičiuojami, dèl to yra labai plačiai naudojami, o kiti (Lerner indeksas (L), Gini koeficientas (G), Theil entropijos indeksas (T)) yra labai sudettingi ir pritaikyti tam tikroms situacijoms (Pavic, Galetic, Piplica, 2016). Du plačiausiai naudojami rinkos koncentracijos rodikliai yra koncentracijos laipsnis ir Herfindalio-Hiršmano indeksas (Kvalseth, 2018). Sexton, Zhang (2001) pabrèžia, kad šie koncentracijos rodikliai paprastai dažniausiai taikomi tik maisto pramonės gamintojų kaip pardavejju vaidmeniui analizuoti, nors jų, kaip žaliavos pirkèjų iš ūkininkų, galia jau seniai yra problema žemès ūkyje. Dėl to šiame empiriniame tyrime RC ir HHI rodikliai bus naudojami pirkejjų koncentracijai Lietuvos žalio pieno rinkoje nustatyti, turint omenyje labai dideli pieno tiekejjų skaičių ir kiekvieno jų labai mažą individualią rinkos dalị.

Rinkos koncentracijos laipsnis $\left(\mathrm{CR}_{\mathrm{n}, \mathrm{t}}\right)$ reiškia didžiausių rinkoje veikiančių įmonių $n$ agreguotą rinkos dalį $t$ metais ir apskaičiuojamas kaip šių įmonių individualių rinkos dalių suma:

$$
C R_{n, t}=\sum_{i=1}^{n} M S_{i, t},
$$

čia $n$ - fiksuotas didžiausių ịmonių skaičius, pvz., 4, 8 ar 50, o $M S_{i, t}-i$-tosios i̇monès rinkos dali $t$ metais. $\mathrm{CR}_{\mathrm{n}, \mathrm{t}}$ rodiklị lengva interpretuoti, nes jis svyruoja nuo 0 iki 100. Kuo arčiau 100, tuo didesnè rinkos koncentracija, t. y. kuo didesnę rinkos dali užima mažas i̇monių skaičius, tuo koncentracija bus didesnè. Paprastai labai didelès rinkos dalys (50 proc. ir daugiau) jau savaime gali rodyti dominuojančią padèti rinkoje (Gairès..., 2004). Cavalleri, Eliet, McAdam, et al (2019) atkreipia dėmesi i i tai, kad 
norint prasmingai interpretuoti $\mathrm{CR}_{\mathrm{n}}$ rodikli, pirmiausia reikia nustatyti tinkamą rinką, t. y. kurias įmones ar produktus reikia ịtraukti apskaičiuojant jų bendrą rinkos dalị. Šiame empiriniame tyrime $n=6$ žymi šešių didžiausių Lietuvos pieno pramonès imonių bendrą supirkto žalio pieno dalį vidaus rinkoje 2010 ir 2018 metais.

Manoma, kad CR kaip rinkos koncentracijos matas yra paprasčiausias ir suprantamiausias rodiklis (Cavalleri, Eliet, McAdam, et al, 2019), tačiau jo trūkumu laikoma tai, kad susitelkiama ị ribotą informaciją (Kwoka Jr, 1985) ir neatsižvelgiama i visų, o tik ị tam tikro fiksuoto skaičiaus didžiausių įmonių pasiskirstymą rinkoje (Pavic, Galetic, Piplica, 2016). Dèl to neišvengiamai atskiriama analizuojamų ịmonių (n) rinka nuo likusių gerokai mažesnes rinkos dalis turinčių įmonių rinkos. Taip pat nepaisoma rinkos dalių nelygybès tarp i̇monių analizuojamoje didžiausių i̇monių grupejje (kuri pati savaime apibrèžta), o parodoma tik nelygybė tarp šios grupès ir visų likusių įmonių (Davies, 1979).

Minètas problemas išsprendžia, kaip nurodoma tiek ankstyvojoje, tiek dabartinèje teorinèje ir taikomojoje literatūroje (pvz., Davies, 1979; Kwoka Jr, 1985; Cavalheiro, Vieira, Costa, 2015; Pavic, Galetic, Piplica, 2016; Cavalleri, Eliet, McAdam, et al, 2019; ir kt.), Herfindalio-Hiršmano indeksas (HHI). Manoma, kad HHI yra tikslesnis rinkos koncentracijos matas, nes jame atsižvelgiama ị santykinị visų imonių pasiskirstymą rinkoje, neignoruojant mažesnių įmonių.

HHI apibrěžiamas kaip visų rinkoje veikiančių įmonių individualių rinkos dalių, palyginti su visa rinkos apimtimi, kvadratų suma:

$$
H H I_{t}=\sum_{i=1}^{n} M S_{i, t}^{2},
$$

čia $M S_{i, t}$ žymi $i$-tosios įmonès rinkos dalị, o $n$ - įmonių skaičius rinkoje $t$ metais. HHI suteikia proporcingai didesnị svorị didesnių imonių rinkos dalims (Horizontal..., 2010). HHI gali svyruoti nuo skaičiaus, artimo nuliui (t. y. 1/n), iki 1, kai rinkos dalis išreikšta dešimtainėmis trupmenomis, arba nuo 10 000/n iki 10 000, kai rinkos dalis išreikšta procentais (pvz., 75 proc., o ne 0,75). HHI arteja prie nulio, jeigu rinkoje veikia daugybė santykinai vienodo dydžio ịmonių, o maksimumą (1 arba 10 000) jis pasiekia, kai rinką kontroliuoja viena įmonè. Tad mažesnès indekso reikšmès reiškia didesnę rinkos dalių sklaidą ir didesnę konkurenciją rinkoje, o kuo indekso reikšmès didesnès, tuo rinka labiau koncentruota ir tuo mažesnè konkurencija joje.

HHI, kaip standartini rinkos koncentracijos matą, plačiai naudoja antimonopolinès ir bankų valdžios institucijos, vertindamos galimą i̇monių susijungimo poveiki konkurencijai (Rhoades, 1995) ir siekdamos užkirsti kelią monopolijų egzistavimui, panaikinti ar bent apriboti esamų monopolijų padarinius (Cavalheiro, Vieira, Costa, 2015). Besiremdamos savo patirtimi, agentūros paprastai suskirsto rinkas ị tris rūšis: nekoncentruotos rinkos, kai HHI mažesnis nei 0,15 (arba 1500); vidutiniškai koncentruotos rinkos, kai HHI nuo 0,15 iki 0,25 (arba nuo 1500 iki 2500) ir labai koncentruotos rinkos, kai HHI didesnis nei 0,25 (arba virš 2500) (Horizontal..., 2010).

Nors manoma, kad HHI yra tikslesnis matas nei CR (Pavic, Galetic, Piplica, 2016), tačiau HHI trūkumu laikoma tai, kaip pastebi Rhoades (1995), kad panašias HHI 
reikšmes turinčių rinkų struktūrinès savybès gali labai skirtis. Pirmiausia, labai skirtingas rinkos dalių paskirstymas, turintis skirtingą konkurencinị poveikị, gali turèti tą pačią HHI reikšmę. Tai leidžia daryti išvadą, kad skirtingoms ekonomikos šakoms gali būti taikomos skirtingos HHI ribos. Pasak Kwoka (1985), bet kokiu atveju nè vienas koncentracijos rodiklis negali atskleisti svarbių tam tikros rinkos ar ūkio šakos bruožų, kurie padètų nustatyti įmonių elgsenos ypatumus. Dėl to, anot autoriaus, koncentracijos išmatavimas nepakeičia išsamios rinkos ekonominès analizès. Kaip teigè Singer (1968, cituota iš Kwoka, 1985, p.947), koncentracijos lygio apskaičiavimas (turint omenyje skirtingus koncentracijos rodiklius) turi būti suvokiamas tik kaip rinkos galios antimonopolinès analizès pradžia.

Kaip nurodo Kvalseth (2018), abu koncentracijos rodikliai (CR ir HHI) neturi tikslaus funkcinio ryšio. Kita vertus, Pavic, Galetic, Piplica (2016), remdamiesi JAV ekonomikos pavyzdžiu atliktais tyrimais, mano, kad nèra skirtumo tarp CR ir HHI, t. y. tarp jų yra specifinis ryšys, kuris leidžia konvertuoti tam tikrą vieno rodiklio reikšmę i atitinkamą kito rodiklio reikšmę ir leidžia daryti panašias išvadas. Pagal abu minètus koncentracijos rodiklius galima spręsti apie rinkos koncentracijos lygi, rinkos tipą ir rinkos galią. Atsižvelgiant i abiejų rodiklių reikšmes, galima kalbèti apie nekoncentruotas rinkas, vidutiniškai koncentruotas rinkas ir labai koncentruotas rinkas. Tačiau literatūroje nèra bendro sutarimo tiek dèl RC ir HHI ribų interpretacijų, tiek dèl abiejų rodiklių reikšmių atitikčių. Pagal vienus autorius $\mathrm{RC}$ intervalai < 45, 45-60 ir $>60$ proc. atitinkamai reiškia nekoncentruotą, vidutiniškai koncentruotą ir labai koncentruotą rinką (Mikhalkina, Maitah, Srédl, 2015). Kiti autoriai ar agentūros labai koncentruota rinka laiko nuo 70 proc. (Dèl Konkurencijos..., 2020) arba nuo 75 proc. (Kvålseth, 2018), dar kiti - nuo 80 proc. ribos (Hall, Tideman (1967). Literatūroje taip pat naudojamos skirtingos HHI reikšmių ribos - dažnai taikomi < 1500, 1500-2500, > 2500 (pvz., Horizontal..., 2010; Pavic, Galetic, Piplica (2016)), taip pat < 1000, 10001800, > 1800 (pvz., Cavalheiro, Vieira, Costa, 2015; Mikhalkina, Maitah, Srédl, 2015) intervalai rinkos koncentracijos lygiui apibrěžti (atitinkamai nekoncentruota, vidutiniškai koncentruota ir labai koncentruota rinka). Šiame empiriniame tyrime žalio pieno rinkos koncentracijos lygiams nustatyti taikomos kituose pieno sektoriaus tyrimuose naudotos RC ir HHI rodiklių ribos, nurodytos 1 lentelèje.

1 lentelè. Žalio pieno rinkos tipai pagal pirkèjų koncentracijos rodiklius

\begin{tabular}{|c|c|c|c|c|}
\hline $\begin{array}{c}\text { Koncentracijos } \\
\text { lygis }\end{array}$ & Rinkos tipas & $\begin{array}{c}\text { Pirkejjų galia } \\
\text { rinkoje }\end{array}$ & Pirkëjų CR6 & Pirkejjų HHI \\
\hline $\begin{array}{c}\text { Nekoncentruota } \\
\text { rinka }\end{array}$ & $\begin{array}{c}\text { Veiksminga } \\
\text { konkurencija }\end{array}$ & $\begin{array}{c}\text { Jokios arba } \\
\text { menka }\end{array}$ & $<45$ & $<1000$ \\
\hline $\begin{array}{c}\text { Vidutiniškai } \\
\text { koncentruota } \\
\text { rinka }\end{array}$ & $\begin{array}{c}\text { Netvirta } \\
\text { oligopsonija }\end{array}$ & Vidutiniška & $45-60$ & $1000-1800$ \\
\hline $\begin{array}{c}\text { Labai } \\
\text { koncentruota } \\
\text { rinka }\end{array}$ & Oligopsonija & Didele & $>60$ & $>1800$ \\
\hline
\end{tabular}

Šaltinis: parengta autorès pagal Cavalheiro, Vieira, Costa, (2015) ir Pavic, Galetic, Piplica (2016). 


\subsection{Tyrimo duomenys ir apribojimai}

Empiriniame tyrime žalio pieno pasiūlos vidaus rinkos koncentracijai išmatuoti naudojami ŽŪIKVC tvarkomos Lietuvos žemès ūkio ir maisto produktų rinkos informacinès sistemos (toliau - LŽŪMPRIS) viešai skelbiami duomenys apie šalies gamintojų žalio pieno pardavimus ir pardavejų skaičių, agreguoti pagal tris ūkiuose laikomų karvių bandos dydžio grupes. Pokyčiams po $2009 \mathrm{~m}$. ekonomikos krizès nustatyti analizuojami 2010-2011 kvotos metų (atitinkamai nuo balandžio 1 d. iki kovo 31 d.) ir kalendorių 2018 metų duomenys.

Paklausos koncentracijai nustatyti naudojami LŽŪMPRIS šiam tyrimui pateikti viešai neskelbiami individualūs pieną superkančių ịmonių duomenys apie 2010 ir 2018 m. perdirbimui supirktą pieno kiekị vidaus rinkoje (pagal LŽŪMPRIS sistemoje užsiregistravusių pieno supirkejjų pateiktą informaciją). Šių įmonių bendro supirkto pieno kiekio nuokrypis nuo Lietuvos statistikos departamento paskelbto supirkto natūralaus riebumo pieno kiekio šalies vidaus rinkoje labai mažas -2010 m. $-0,14$ proc., o 2018 m. -0,51 proc. Kaip apie rinkos koncentracijos tyrimus rašę Hall, Tideman (1967, p. 163) pastebejjo, ,bendras pramonès įmonių skaičius paprastai nėra žinomas labai tiksliai“.

\section{Tyrimo rezultatai}

\section{Žalio pieno pardaveju pasiskirstymas rinkoje}

Paskutinio $2016 \mathrm{~m}$. žemès ūkio struktūros tyrimo duomenimis, Lietuvoje melžiamas karves laikẻ daugiau kaip 55,4 tūkst. didesnių nei 1 ha ūkių. Visi bendrai jie laikẻ 302,3 tūkst. karvių. Net 91 proc. ūkių bandos buvo mažesnès nei 10 karvių, o 100 karvių ir didesnes bandas laikè tik 259 ūkiai, sudarę vos pusę procento visų pieno gamintojų šalyje. Be to, karves laiko ir mažesni nei 1 ha ūkiai, kurie į minètą žemès ūkio struktūros tyrimą nepateko. $2010 \mathrm{~m}$. žemès ūkio surašymo duomenimis, tokių ūkių buvo 7,7 tūkst., tikètina, kad 2016 m. jų galèjo būti perpus mažiau.

ŽŪIKVC duomenimis, tais pačiais 2016 metais žalią pieną perdirbimui pardavè 28,7 tūkst. gamintojų, kas sudarè apie 39 proc. nuo visų karves laikiusių ūkių. Per kooperatines bendroves ( kooperatyvus) pieną pardavè daugiau kaip 8 tūkst. ūkių, kas sudarè 28,1 proc. nuo visų pieną perdirbimui tiekusių ūkių. 27 individualiai veikiantys (neasocijuoti) kooperatyvai iš jų supirko 370,7 tūkst. $t$ žalio pieno ir tai sudare 26,3 proc. visos pasiūlos vidaus rinkoje. Šią analizę papildant 2 lentelèje pateiktais duomenimis apie žalio pieno pardavèjų ir jų pasiūlos pasiskirstymą rinkoje pagal laikomų karvių bandos dydị (net 70,5 proc. visų pieną parduodančiu gamintojų Lietuvoje yra labai maži, laikantys iki 5 melžiamų karvių), galima daryti išvadą, kad žalio pieno pasiūla vidaus rinkoje dekoncentruota, o neasocijuoti kooperatyvai realios derybinès galios rinkoje neturi. Be to, iki šiol Lietuvoje neiregistruota nei viena pieno gamintojų organizacija. 
2 lentelè. Žalio pieno pardavejai ir pardavimai pagal ūkiuose laikomų karvių bandos dydi

\begin{tabular}{|c|c|c|c|c|c|c|c|c|}
\hline \multirow{3}{*}{$\begin{array}{c}\text { Karviu bandos } \\
\text { dydis }\end{array}$} & \multicolumn{4}{|c|}{ 2010-2011 kvotos metais } & \multicolumn{4}{|c|}{2018 kalendoriniais metais } \\
\hline & \multicolumn{2}{|c|}{$\begin{array}{l}\text { Gamintojai / } \\
\text { pardavèjai }\end{array}$} & \multicolumn{2}{|c|}{ Parduotas pienas } & \multicolumn{2}{|c|}{$\begin{array}{l}\text { Gamintojai / } \\
\text { pardavèjai }\end{array}$} & \multicolumn{2}{|c|}{ Parduotas pienas } \\
\hline & sk. & proc. & tūkst. t & proc. & sk. & proc. & tūkst. t & proc. \\
\hline $1-5$ karvès & 29736 & 71,9 & 198,8 & 15,4 & 16072 & 70,5 & 168,6 & 12,4 \\
\hline 6-14 karvès & 8155 & 19,7 & 263,3 & 20,3 & 3668 & 16,1 & 152,3 & 11,2 \\
\hline $\begin{array}{l}15 \text { ir daugiau } \\
\text { karvių }\end{array}$ & 3478 & 8,4 & 831,6 & 64,3 & 3071 & 13,5 & 1035,1 & 76,3 \\
\hline Iš viso & 41369 & 100,0 & 1293,7 & 100,0 & 22811 & 100,0 & 1356,0 & 100,0 \\
\hline
\end{tabular}

Remiantis LR konkurencijos tarybos (2015) atlikto pieno ir pieno produktu rinkos tyrimo išvadomis, didelè dalis šiuo metu Lietuvoje veikiančių kooperatyvų galimai nèra „tikrieji“ - vien savo narių tiekiamu pienu paremti - kooperatyvai, o jų veikla labiau panaši ị tarpininkų veiklą. Dalis kooperatyvų turi 5 ar mažiau narių, iš kurių superkama itin maža žalio pieno dalis (yra ir pieno negaminančiu narių), o didžioji dalis superkama iš kitų gamintojų. Trečdalis apklaustų kooperatyvų nurodė neturintys derybinès galios, derantis su pieno perdirbejais dèl pieno pardavimo kainų, arba ji yra maža. Daugiau nei penktadalis apklausoje dalyvavusių didesnių kooperatyvų, kurie superka pakankamai didelius žalio pieno kiekius, savo derybinę galią vertino teigiamai.

\section{Žalio pieno pirkèjų koncentracija}

Lietuvoje žalią pieną superka ji perdirbančios įmonès bei kiti jị perparduodantys tarpininkai: kooperatyvai, individualios įmonès, akcinès bendrovès ir kt. (LR konkurencijos taryba, 2015). 2 paveiksle pateiktos dvi pirkèjų koncentracijos kreivès vaizduoja, kaip minètų pirkèjų kumuliatyvi dalis susijusi su Lietuvos vidaus rinkoje supirkto žalio pieno kumuliatyvia dalimi, kai pirkèjai yra išdėstyti mažejimo tvarka pagal metini supirkto pieno kiekį. Dèl to abi kreivès nuolat kyla iš kairès pusès palaipsniui mažejančiu tempu. Kiekvienos kreivès aukštis virš bet kurio horizontalios ašies taško išmatuoja kumuliatyvią iš šalies gamintojų supirkto žalio pieno dalį.

Kaip ir buvo galima tikètis, vidaus rinkoje 2010 ir 2018 m. supirkto žalio pieno pirkèjų koncentracijos kreivès yra virš tolygaus paskirstymo įstrižinès linijos ir labai išgaubtos. Tai rodo labai netolygų superkamo žalio pieno kiekio pasiskirstymą tarp pirkèjų Lietuvos vidaus rinkoje - didžiają dali superka kelios didžiausios pieno pramonès įmonès, o likusieji pirkẻjai užima po mažą rinkos dalį. Viena prie kitos labai prigludusios kreivès, nubrèžtos pagal tyrimo laikotarpio pradžios ir pabaigos duomenis, rodo labai menkus koncentracijos pokyčius Lietuvos žalio pieno rinkoje. Detalesni duomenys pateikti 3 lentelèje.

\footnotetext{
${ }^{1}$ Rinkos tyrimo metu klausimynai buvo išsiųsti 73 patvirtintiems supirkejjams. Iš apklaustų ūkio subjektų identifikuoti 42 kooperatyvai, 13 pieno perdirbèjų, o likusieji uždarosios akcinès bendrovès, individualios įmonès ir kt. (LR Konkurencijos taryba, 2015).
} 


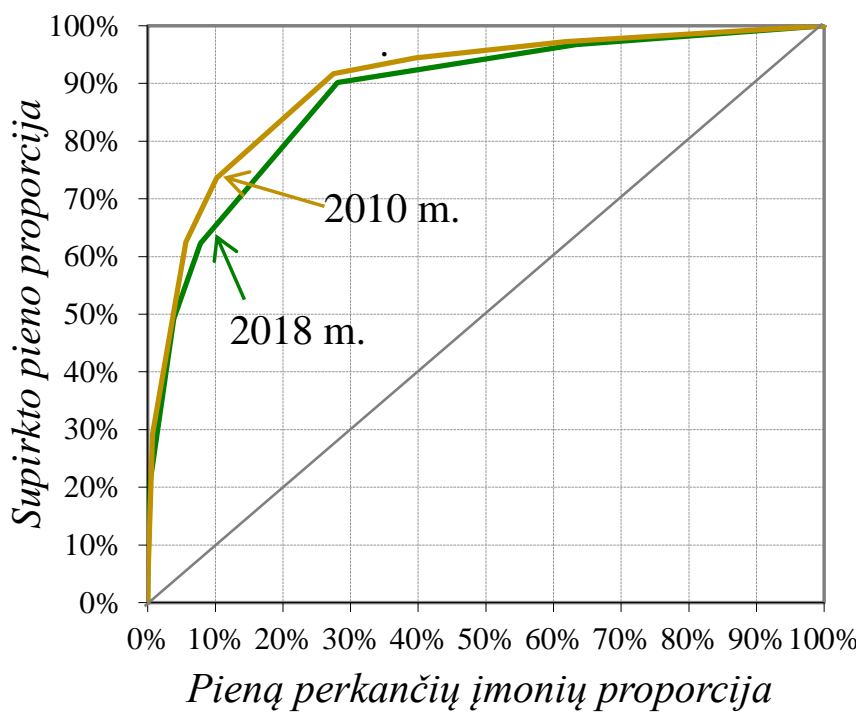

2 pav. Žalio pieno supirkimo Lietuvos vidaus rinkoje koncentracijos kreivès Šaltinis: parengta autorès pagal LŽŪMPRIS pateiktus individulių ịmonių duomenis

Kaip rodo 3 lentelèje pateikti koncentracijos laipsnio (CR6) duomenys, $2010 \mathrm{~m}$. šešios didžiausios pieną perdirbančios įmonès (arba 8 proc. iš 76 pirkejjų) supirko beveik 72,5 proc. žalio pieno vidaus rinkoje. Iki $2018 \mathrm{~m}$. pirkejjų žalio pieno rinkoje sumažèjo penktadaliu, o šešių didžiausių pieno perdirbime pirmaujančių įmonių - $A B$ „Pieno žvaigždès“, AB „Rokiškio sūris“, AB „Žemaitijos pienas“, AB Vilkyškių pieninè, Ž $\bar{U} K$ „Pienas LT“ ir UAB „Marijampolès pieno konservai“ - bendra pieno supirkimų dalis sumažèjo iki 71,9 proc. Šie rezultatai Lietuvos žalio pieno vidaus rinką leidžia apibūdinti kaip oligopsoninę, turinčią šešias didelès galios pieno perdirbimo imones (žr. 1 lentelëje pareiktas charakteristikas pagal CR6 ribines reikšmes). Kaip teigia Cavalleri, Eliet, Petroulakis, et al. (2019), aukštas koncentracijos laipsnis rinkoje parodo slapto susitarimo galimybę, be to, mažejant įmonių skaičiui, tikètina, kad galimybè slaptam susitarimui sudaryti dar labiau didès.

3 lentelè. Pirkejjų koncentracija žalio pieno vidaus rinkoje Lietuvoje

\begin{tabular}{|c|c|c|c|c|}
\hline \multirow{2}{*}{$\begin{array}{l}\text { Supirkto pieno apimties } \\
\text { grupès ir koncentracijos } \\
\text { rodikliai }\end{array}$} & \multicolumn{2}{|c|}{2010} & \multicolumn{2}{|c|}{2018} \\
\hline & Pirkèjų sk. & $\begin{array}{c}\text { Supirkta pieno } \\
\text { tūkst. t }\end{array}$ & Pirkèjų sk. & $\begin{array}{c}\text { Supirkta pieno } \\
\text { tūkst. t }\end{array}$ \\
\hline$<0,1$ tūkst. $\mathrm{t}$ & 7 & 0,22 & 4 & 0,19 \\
\hline $0,1-<1$ tūkst. $\mathrm{t}$ & 18 & 9,01 & 9 & 5,06 \\
\hline $1-<5$ tūkst. $\mathrm{t}$ & 24 & 62,61 & 17 & 47,01 \\
\hline $5-<10$ tūkst. t & 8 & 58,25 & 8 & 53,47 \\
\hline $10-<50$ tūkst. $\mathrm{t}$ & 13 & 220,73 & 17 & 275,00 \\
\hline $50-<100$ tūkst. $\mathrm{t}$ & 2 & 154,39 & - & - \\
\hline $100-<200$ tūkst. $\mathrm{t}$ & 2 & 283,14 & 4 & 479,20 \\
\hline$\geq 200$ tūkst. $\mathrm{t}$ & 2 & 488,10 & 2 & 496,10 \\
\hline Iš viso & 76 & 1276,5 & 61 & 1356,0 \\
\hline CR6 & \multicolumn{2}{|c|}{72,5} & \multicolumn{2}{|r|}{71,9} \\
\hline $\mathrm{HHI}$ & \multicolumn{2}{|c|}{1104} & \multicolumn{2}{|r|}{1018} \\
\hline
\end{tabular}

Šaltinis: parengta autorès pagal LŽŪMPRIS pateiktus individulių ịmonių duomenis 
Pagal visų pirkèjų individualius duomenis apskaičiuoti Herfindalio-Hiršmano indekso (HHI) balai tyrimo laikotarpio pradžioje ir pabaigoje (3 lentelëje) rodo, kad koncentracija žalio pieno vidaus rinkoje po 2009 m. ekonomikos krizès šiek tiek sumažèjo (tą pačią tendenciją rodo ir CR6 rodiklis bei koncentracijos kreivių grafikas). Gauti HHI balai, patenkantys ị 1 lentelèje nurodytą šio indekso vidurini intervalą, leidžia Lietuvos žalio pieno vidaus rinką klasifikuoti kaip vidutiniškai koncentruotą netvarios oligopsonijos rinką, o joje pirmaujančių pieno pramonės įmonių rinkos galią - kaip vidutinę.

\section{Išvados}

Pagal standartinę žemės ūkio produktų rinkos struktūros koncepciją žalio pieno, kaip ir visų žemès ūkio produktų, rinka ekonomikos teorijoje klasifikuojama kaip tobula konkurencija - joje daugybė tokių pačių produktų gamintojų ir standartus atitinkančios šių produktų perdirbejjų, be kliūčių galima patekti ị šią rinką, joje lygiai visiems prieinama informacija. Tačiau tai veikiau hipotetinis, o ne dabartinę realią situaciją žalio pieno rinkoje Lietuvoje, kaip ir kitose šalyse, apibūdinantis modelis. Didejantis maisto grandinès konsolidavimas ir vertikalusis koordinavimas sudare galimybę galingoms pieno pramonès ir mažmeninès prekybos ịmonėms mažinti iš ūkių superkamo žalio pieno kainas. Antra vertus, pieno gamintojų jungtinès veiklos organizacijų (kooperatyvų, gamintojų organizacijų ir kt.) didelès rinkos dalys gali priversti ji perdirbančias įmones mokèti didesnes kainas gamintojams ir sumažinti jų svyravimą.

Lietuvos žalio pieno vidaus rinkoje pasiūla yra dekoncentruota, o neasocijuoti kooperatyvai realios derybinès galios gamintojams rinkoje iki šiol nesukūrè. Be to, Lietuvoje neiregistruota nei viena pieno gamintojų organizacija. Antra vertus, didelis šešių pieną perdirbančių įmonių koncentracijos rinkoje laipsnis Lietuvos žalio pieno vidaus rinką apibūdina kaip oligopsoninę, turinčią didelès galios rinką. Aukštas koncentracijos laipsnis rinkoje sukuria slapto susitarimo galimybę, be to, mažejant ìmonių skaičiui, tikètina, kad galimybė slaptam susitarimui sudaryti dar labiau didès.

Empiriniame tyrime pagal pieną superkančių ìmonių individualius duomenis gautos RC ir HHI reikšmès atskleidè vienodą pirkejjų koncentracijos lygio kitimo nuo $2010 \mathrm{~m}$. tendenciją. Gi pagal rinkos koncentracijos lygiui ir rinkos tipui nustatyti taikytas ribas abiejų rodiklių gautos reikšmès kiek skirtingai apibūdina Lietuvos žalio pieno vidaus rinkos struktūrą, t. y. pagal RC - kaip labai koncentruotą oligopsoninę rinką, o pagal HHI - kaip vidutiniškai koncentruotą netvirtos oligopsonijos rinką. To priežastimi gali būti HHI trūkumas, kai panašias jo reikšmes turinčių rinkų struktūrinès savybès gali labai skirtis pagal ekonomikos šakas, ir, galbūt, pienininkystès šakai taikytinos kitos HHI ribos. Tad, atliepiant metodikoje minètas Kwoka (1985) pastabas apie tai, jog nè vienas koncentracijos rodiklis negali atskleisti svarbių tam tikros rinkos ar ūkio šakos bruožų, kurie padètų nustatyti įmonių elgsenos ypatumus, o CR ir HHI išmatavimas nepakeičia išsamios rinkos ekonominès analizès, tikslinga atlikti išsamesnį žalio pieno rinkos koncentracijos tyrimą. 


\section{Literatūra}

Cavalheiro, E. A., Vieira, K. M., \& Costa, C. (2015) Market concentration in US milk processors and his influence at price paid to cow milk producers // Corporate Ownership \& Control. No. 13(1): 627-634.

Cavalleri, M. C., Eliet, A., McAdam, P., Petroulakis, F., Soares, A. C., \& Vansteenkiste, I. (2019). Concentration, Market Power and Dynamism in the Euro Area. Europen Central Bank. Working Paper Series No. 2253 / March 2019.

Cramer Jr., G. L., Jensen, C. W., Southgate, D. D. (1997). Agricultural economics and agribusiness. New York: John Wiley \& Sons, Inc. 177.

Davies, S. (1979). Choosing between concentration indices: The iso-concentration curve // Economica. No. 46: 67-75.

Dèl Konkurencijos tarybos paaiškinimų dèl dominuojančios padèties nustatymo. LR Konkurencijos tarybos $2000 \mathrm{~m}$. gegužès $17 \mathrm{~d}$. nutarimas Nr. 52. Vilnius.

Gairès dẻl horizontalių susijungimų vertinimo pagal Tarybos reglamentą dèl koncentracijų tarp imonių kontrolès. (2004/C 31/03). Oficialusis leidinys C 031, 05/02/2004, p. 0005 - 0018 https://eur-lex.europa.eu/legal-ontent/LT/TXT/PDF/?uri=CELEX:52004XC0205(02)\&from=EN [2019 11 26].

Grau, A., \& Hockmann, H. (2018). Market power in the German dairy value chain // Agribusiness. No. 34(1): 93-111.

Guth, L. A., Schwartz, R. A., \& Whitcomb, D. K. (1976). The use of buyer concentration ratios in tests of oligopoly models // The Review of Economics and Statistics. No. 58(4): 488-492.

Hall, M., \& Tideman, N. (1967). Measures of concentration // Journal of the American statistical association. No. 62(317): 162-168.

Hanson, P., \& Simmons, P. (1995). Measures of buyer concentration in the Australian wool market // Review of Marketing and Agricultural Economics. No. 63: 304-310.

Horizontal Merger Guidelines. (2010). U.S. Department of Justice and the Federal Trade Commission. Issued: August 19. -https://www.justice.gov/sites/default/files/atr/legacy/2010/08/19/hmg-2010.pdf [2019 11 26]

Kakwani, N. C. (1977). Applications of Lorenz curves in economic analysis // Econometrica: Journal of the Econometric Society. No. 45(3): 719-727.

Kvålseth, T. O. (2018). Relationship between concentration ratio and Herfindahl-Hirschman index: A re-examination based on majorization theory. Heliyon, 4(10), e00846. https://doi.org/10.1016/j.heliyon.2018.e00846.

Kwoka Jr, J. E. (1985). The Herfindahl index in theory and practice //Antitrust Bull. No. 30: 915946.

LR Konkurencijos taryba. (2015). Lietuvos Respublikos konkurencijos tarybos pranešimas apie atliktą pieno ir pieno produktų sektoriaus rinkos tyrimą. Bylos Nr. 14//1/1/08/33/077. 2015-0621, Nr. 5S-14/2015, Vilnius.

Madau, F. A., Furesi, R., \& Pulina, P. (2016). The existence of buyer power in the Italian fresh milk supply chain // British Food Journal. No. 118(1): 70-82.

Mikhalkina, E., Maitah, M., \& Srédl, K. (2015). Measuring market structures in the dairy market in the Czech Republic // Asian Social Science. No. 11(21): 306-315.

Müller, M., Hanisch, M., Malvido, A., Rommel, J., \& Sagebiel, J. (2018). The structural effect of cooperatives on price volatility in the European dairy sector //Applied Economics Letters. No. 25(8): 576-579.

OECD. (2005). Competition and Regulation in Agriculture: Monopsony Buying and Joint Selling. DAF/COMP(2005)44.

OECD. (2018). Market Concentration. Issues paper by the Secretariat 6-8 June 2018. Directorate for Financial and Enterprise Affairs Competition Committee. DAF/COMP/WD(2018)46. 
Pavic, I., Galetic, F., \& Piplica, D. (2016). Similarities and differences between the CR and HHI as an indicator of market concentration and market power // Br. J. Econ. Manag. Trade. No. 13(1): $1-8$.

Rhoades, S. A. (1995). Market share inequality, the HHI, and other measures of the firm-composition of a market // Review of industrial organization. No. 10(6): 657-674.

Rogers, R. T. (2001). Structural change in US food manufacturing, 1958-1997// Agribusiness. No. 17(1): 3-32.

Rosenbluth, G. (1955). Measures of concentration. In Business concentration and price policy (pp. 57-99). Princeton University Press.

Scalco, P. R., \& Braga, M. J. (2014). Measuring the degree of oligopsony power in the Brazilian raw milk market // International Food and Agribusiness Management Review. No. 17: 1-20.

Sexton, R. J. (1990). Imperfect competition in agricultural markets and the role of cooperatives: a spatial analysis //American Journal of Agricultural Economics. No. 72(3): 709-720.

Sexton, R. J., \& Xia, T. (2018). Increasing concentration in the agricultural supply chain: implications for market power and sector performance // Annual Review of Resource Economics. No. 10: 229-251.

Sexton, R. J., \& Zhang, M. (2001). An assessment of the impact of food industry market power on US consumers // Agribusiness. No. 17(1): 59-79.

Stalgienè, A., \& Jedik, A. (2015). Oligopsoninė galia žemės ūkio produktų rinkoje: Lietuvos žalio pieno rinkos atvejis // Vadybos mokslas ir studijos-kaimo verslų ir jų infrastruktūros plètrai. Nr. 37(1): 114-121.

Van Kerm, P., \& Jenkins, S. P. (2001). Generalized Lorenz curves and related graphs: an update for Stata 7. // The Stata Journal. No. 1(1): 107-112.

Wysokinski, M., Baran, J., \& Florkowski, W. J. (2015). Concentration of milk production in Poland // Economic Science for Rural Development. No. 37: 93-104.

Yitzhaki, S., \& Olkin, I. (1991). Concentration indices and concentration curves // Lecture NotesMonograph Series. Stochastic Orders and Decision under Risk. No. 19: 380-392.

\title{
STRUCTURE AND CONCENTRATION OF DOMESTIC MARKET OF RAW MILK IN LITHUANIA
}

\author{
Vlada Vitunskienè \\ Vytautas Magnus University \\ Address: K. Donelaičio g. 58, 44248, Kaunas, Lithuania
}

Received 1111 2019, Accepted 08122019

\section{Summary}

The study addresses the problem of assessing raw milk market concentration on both sides supply and demand - when researchers have very limited information on sales and purchases of milk producers (i.e. sellers), dairy manufacturers and other raw milk resellers (i.e. buyers) at the individual level. Based on abstract modelling, the normalized Lorenz curve, comparative analysis of the concentration ratio (RC) and the Herfindahl-Hirschman index (HHI) and their dynamics, a hypothetical model of structural elements of raw milk market was developed, and concentration level on Lithuanian domestic raw milk market was determined. The empirical findings show that, on the one hand, the supply of raw milk on the domestic market is deconcentrated and that unassociated cooperatives do not create real producers' bargaining power on the market. On the other hand, high values of RC6 allow for classifying this market as oligopsony market, with an almost stable concentration of buyers (the concentration has slightly decreased after the 2009 economic crisis). 